\title{
Potential applications of nanotechnology in the agro-food sector
}

\author{
Potenciais aplicações de nanotecnologia no setor agro-alimentar
}

\author{
Mario GARCÍA ${ }^{1 *}$, Tamara FORBE ${ }^{1}$, Eric GONZALEZ ${ }^{2}$
}

\begin{abstract}
Nanoscience and nanotechnology are new frontiers of this century. Their application to the agriculture and food sectors is relatively recent compared with their use in drug delivery and pharmaceuticals. Smart delivery of nutrients, bioseparation of proteins, rapid sampling of biological and chemical contaminants, and nanoencapsulation of nutraceuticals are some of the emerging topics of nanotechnology for food and agriculture. In this review, some applications of nanotechnology in agro-food sector are discussed.

Keywords: nanotechnology; nanocomposite; nutraceuticals; nano-delivery system; carbon nanotubes.
\end{abstract}

\section{Resumo}

Nanociências e nanotecnologia são fronteiras novas deste século. Suas aplicações à agricultura e ao setor alimentar são relativamente recentes quando comparadas com a sua utilização em entrega de fármacos. Entrega inteligente de nutrientes, biosseparação de proteínas, amostragem rápida de contaminantes químicos e biológicos e nanoencapsulamento de nutracêuticos são alguns dos tópicos emergentes relativamente à aplicação de nanotecnologia em agricultura e alimentação. Nesta revisão, abordam-se possíveis aplicações de nanotecnologia no sector agroalimentar.

Palavras-chave: nanotecnologia; nanocompósitos; nutracêuticos; nanossistema de entrega; nanotubos de carbono.

\section{Introduction}

Nanotechnology has captured the imagination of researchers, manufacturers, and even the general population in recent years. Nanotechnology is generally seen as a new and fast emerging field that involves the manufacture, processing, and application of structures, devices and systems by controlling the shape and size at the nanometer scale. Nanoparticles (NPs) are defined as $[\ldots]$ a discrete entity that has three dimensions of the order of $100 \mathrm{~nm}$ or less [...] (SCIENTIFIC..., 2007, p. 13). It is this small size in combination with the chemical composition and surface structure that gives NPs their unique features and huge potential for applications.

Two building strategies are currently used in nanotechnology: 1) the "top down" approach, in which nano-level structures are generated by breaking up bulk materials, using milling, nanolithography, or precision engineering; and 2) the newer "bottom up" approach, which allows nanostructures to be built from individual atoms or molecules that are capable of selfassembling (MORARU et al., 2003).

The application of NPs in electronics, medicine, textiles, defense, food, agriculture, cosmetics, and other areas is already a reality and the applications are beginning to impact food-associated industries (MAYNARD et al., 2006; CHEN; WEISS; SHAHIDI, 2006). In food and agricultural systems nanotechnologies cover many aspects, such as food safety, packaging materials, disease treatment, delivery systems, bioavailability, new tools for molecular and cellular biology, and new materials for pathogen detection (MAYNARD et al., 2006; CHEN; WEISS; SHAHIDI, 2006; WEISS; TAKHISTOV; McCLEMENTS, 2006). It is likely that it is only a matter of time until we see the products of nanotechnology "on our plate."

Although potential beneficial effects of nanotechnologies are generally well described, the potential (eco) toxicological effects and impacts of NPs have so far received little attention. The high speed of introduction of NP-based consumer products observed nowadays urges the need to generate a better understanding about the potential negative impacts that NPs may have on biological systems (BOUWMEESTER et al., 2009). Some recent studies have shown that indeed there are reasons to suspect that NPs may display toxicological effects on biological systems (NEL et al., 2006; OBERDORSTER; STONE; DONALDSON, 2007; DONALDSON; SEATON, 2007).

In this review, some applications of engineered NPs and nanotechnology in the agro-food production chain are discussed.

\section{Nanotechnologies in food sector}

Nanotechnology has the potential to revolutionize the global food system. Novel agricultural and food safety systems, disease-treatment delivery methods, tools for molecular and cellular biology, sensors for pathogen detection, pesticides, packaging materials, environmental protection, and education

Recebido para publicação em 17/2/2010

Aceito para publicação em 18/5/2010 (004436)

${ }^{1}$ Pharmacy and Food Institute, University of Havana, Av. 23, n. 21425, CP 13600, Havana, Cuba, E-mail: marioifal@gmail.com

${ }^{2}$ Higher Polytechnic Institute José A. Echeverría, Havana, Cuba

${ }^{*}$ A quem a correspondência deve ser enviada 
of the public and future workforce are examples of the important impact that nanotechnology could have on the science and engineering of agriculture and food systems (MORARU et al., 2003; BOUWMEESTER et al., 2009).

The four major areas in food industry that will probably be significantly enhanced by nanotechnology are development of new functional materials; micro- and nanoscale processing; product development; and design of methods and instrumentation for food safety and biosecurity (MORARU et al., 2003). The potential applications of nanotechnology in the agro-food production chain are claimed to be applicable throughout all phases of food production (Chart 1).

The inclusion of products into Chart 1 is based on labeling information on the product as provided by the manufacturer. The claim that these products contain nanotechnology cannot be verified from the information presented. This also applies to the information on the presence and/or type of NPs in these products. It can be expected that the claim 'nanotechnology' is wrongfully present or absent on the label of some products. The latter situation might even be more critical. Nevertheless, Chart 1 , as shown, gives direction on the type of products that could found on the market, including areas of use. Both scientists and regulators should be aware of this and use this information in the prioritization of research (BOUWMEESTER et al., 2009).

\subsection{Agricultural production}

During primary production, nano-formulated agrochemicals are employed to increase the efficacy of the agrochemicals compared to conventional formulations. Only some pesticides containing nano-sized or nano-formulated agrochemicals were identified as available on the market. Residues of these products might be present in products as consumed.
Furthermore, NPs are used for water and soil cleaning purposes. Carry-over of the used NPs to crops cannot be excluded, resulting in potential consumer exposure (BOUWMEESTER et al., 2009). Examples of used NPs are aluminium oxide, lanthanum particles and nanoscale iron powder in the process of water purification and/or soil cleaning (Chart 2).

Nanostructured materials exhibit unique properties that open windows of opportunity for the creation of new, high performance materials, which will have a critical impact on food manufacturing, packaging, and storage. Nanostructuring adds value to traditional materials by enhancing their mechanical strength, superconductivity, and ability to incorporate and efficiently deliver active substances into biological systems, at low costs and with limited environmental impact.

\subsection{Food processing}

Nanotechnologies are applied in food production machinery. Examples of this type of nanotechnology are coatings of machines or the use of nano-sieves (e.g., to filter out bacteria). While direct food contact is evident, this application of nanotechnology is expected to have negligible additional safety concerns in comparison with conventional techniques since carry-over to food is expected to be negligible. The type of material (and wear-off as a result of the use) of filters or coatings might require some attention, but this is not exclusively related to safety of nanotechnologies (BOUWMEESTER et al., 2009).

Current nanotechnology applications in the agro-food production chain are focused on the development of nano-sized food ingredients and additives, delivery systems for bioactive compounds, and innovative food packaging (CHAUDHRY et al., 2008). As a consequence of their small size, NPs show different physical and chemical properties compared to their respective

Chart 1. Applications of nanotechnology in the agro-food sector (BOUWMEESTER et al., 2009).

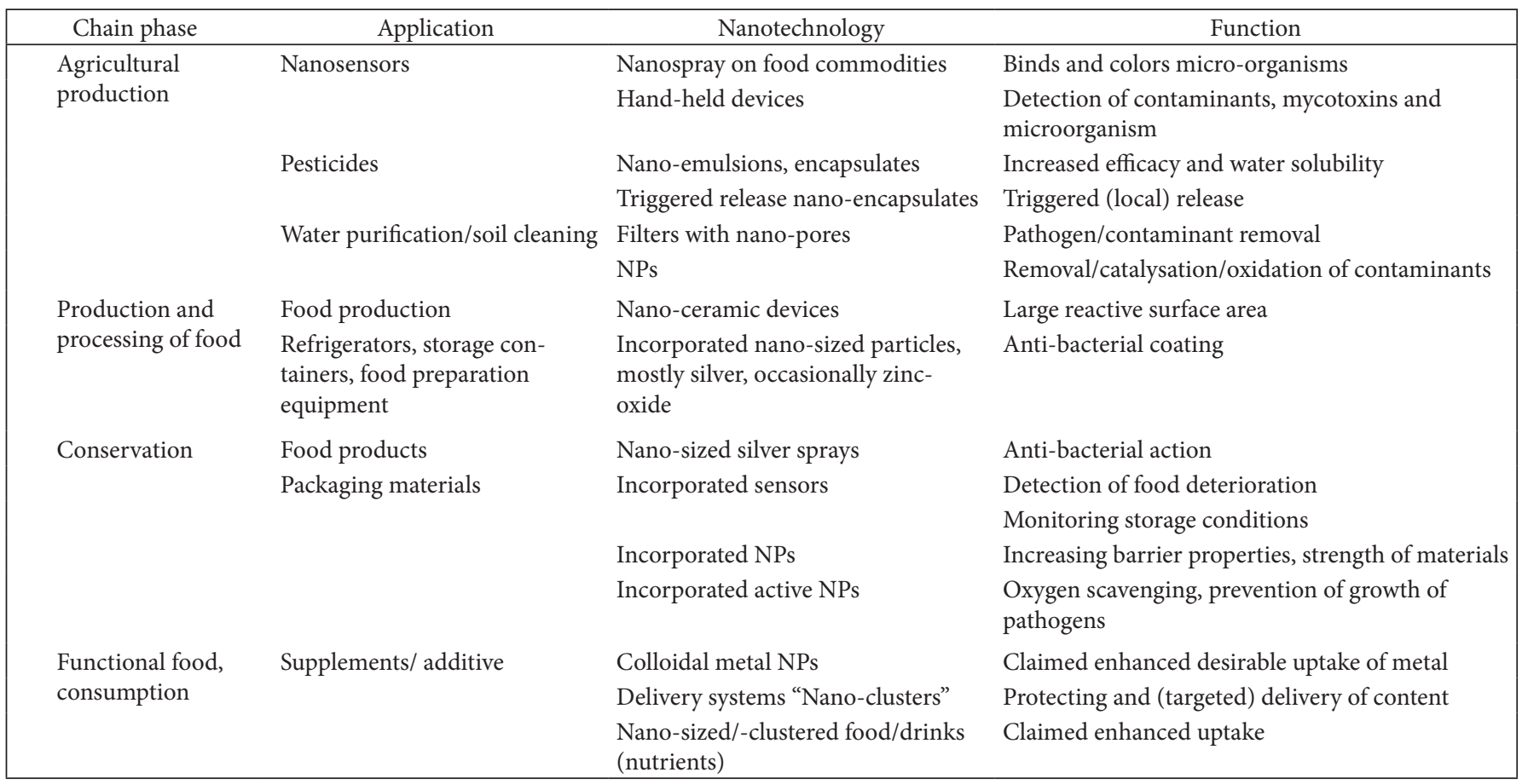


conventional-sized materials, which probably results in different biological interactions. Those physical and chemical properties are thus relevant for the assessment of the possible associated hazards (BOUWMEESTER et al., 2009).

\subsection{Nanoparticles and nano-emulsions}

NPs in food may appear in suspensions (mostly solid in liquids) or emulsions (two liquid phases). Within the agrofood chain, metal or metal-oxide NPs are applied (e.g., nano$\mathrm{Ag}$, nano- $\mathrm{ZnO}$, nano- $\mathrm{Cu}$, nano- $\mathrm{TiO}_{2}$ ). These particles are known to have different structures and shapes, which can be (homogeneous or heterogeneous) spherical, tubular, irregularly (non-spherical) shaped, or can exist in fused aggregated or agglomerated forms.

These characteristics are important with respect to potential risks for health or environment and determine their fate and behavior in the environment, humans, and other organisms (BOUWMEESTER et al., 2009).

\subsection{Food packaging and preservation}

Indirect contamination of food can be expected when NPs or nanotechnological devices are incorporated into packaging materials or storage containers in order to lengthen the shelf life while keeping the products fresh. This type of application is seen as the most important of nanotechnologies in the food sector for the near future (CHAUDHRY et al., 2008). Recently, the Woodrow Wilson International Center for Scholars has published a review dealing with both the applications and regulatory (and toxicological) issues related to NPs incorporated in food packaging materials (WOODROW..., 2008).

A promising class of new materials is represented by nanocomposites made of nanoscale structures with morphology and interfacial properties that give them unique characteristics.
The manufacturing of the first nanocomposites was inspired by biomineralization, the process in which an organic substance (protein, peptide, or lipid) interacts with an inorganic substance (e.g., calcium carbonate) and forms materials with increased firmness (MORARU et al., 2003). An example is a packaging material composed of potato starch and calcium carbonate. This foam has good thermal insulation properties, is lightweight and biodegradable, and has been developed to replace the polystyrene "clam-shell" used for fast food (STUCKY, 1997).

NPs are for instance incorporated to increase the barrier properties of packaging materials (e.g., silicate NPs, nanocomposites, and nano-silver, magnesium- and zinc-oxide). When the NPs are applied into the food packaging materials, direct contact with food is only possible following migration of the NPs. The migration of metals from the biodegradable starch/clay nanocomposite films used in packaging materials for its gas barrier properties to vegetable samples was shown to be minimal (AVELLA et al., 2005), but more studies are needed to reach a conclusive statement.

Nanocomposites are regarded as the potentially ideal solution for plastic beer bottles since previous attempts to use plastic for this application have resulted in spoilage and flavor problems. A Japanese company, Nano Material Inc., developed a microgravure process for coating plastic films such as PET with a nanocomposite barrier material, which is a better-performing, transparent alternative to silica and alumina-coated food packaging films (MOORE, 1999).

Nanostructures can be also built from natural materials. Natural smectite clays, particularly montmorillonite, a volcanic material that consists of nanometer-thick platelets, are a popular source for producing nanoclays (QUARMLEY; ROSSI, 2001). Some companies in the U.S., such as Nanocor Inc. and Southern Clay Products use montmorillonite as an additive in nanocomposites production. The addition of only $3-5 \%$ montmorillonite makes plastics lighter, stronger, and more heat-resistant, and it provides improved barrier

Chart 2. Nanoparticles applied in the food industry (BOUWMEESTER et al., 2009).

\begin{tabular}{|lll|}
\hline \multicolumn{1}{|c|}{ Type of NP } & \multicolumn{1}{c|}{ Application } & \multicolumn{1}{c|}{ Function } \\
\hline Metal nanoparticles (Silver, ZnO) & Food additive/supplement & Claimed enhanced gastrointestinal uptake of metal \\
& Packaging materials/storage & Increase barrier properties \\
& Food preparation devices & Clean surface \\
& Refrigerators, storage containers & Anti-bacterial coating \\
& Water purification/soil cleaning & Removal/catalysation/oxidation of contaminants \\
& Sprays & Anti-bacterial \\
Complex nanoscale structures & Nanosensors in packaging & Detection of food deterioration \\
& Hand-held devices & Monitoring storage conditions detection of contami- \\
& & nants etc. \\
Incorporated active nanoparticles & Migration out of packaging materials & Oxygen scavenging, prevention of growth of pathogens \\
Filters with nano-pores & Water purification & Removal pathogens, contaminants \\
& Equal sized emulsions & Product design (e.g., taste, texture) \\
Nano-sized nutrients / food & Food additive/supplement & Claimed enhanced uptake \\
Delivery systems (nano-encapsulates) & Food additive/supplement & Protecting and (targeted) delivery of content \\
& Pesticide & Increased efficacy, water solubility and crop adherence, \\
& & triggered (local) release \\
\hline
\end{tabular}


properties against oxygen, carbon dioxide, moisture, and volatiles. These characteristics are extremely useful for food packaging applications, and their use could enhance considerably the shelf life of foods such as processed meats, cheese, confectionery, cereals, and boil-in-bag foods. They can also be used in the extrusion manufacturing of fruit juice and dairy foods packaging, or beer and carbonated drink bottles (MORARU et al., 2003).

The application of nanocomposites promises to expand the use of edible and biodegradable films (LAGARÓN et al., 2005). It will help to reduce the packaging waste associated with processed food and will support the preservation of fresh foods extending their shelf life (LABUZA; BREENE, 1988; VERMEIREN et al., 1999).

Polymer composites are mixtures of polymers with inorganic or organic additives with certain geometries (fibres, flakes, spheres, particulates). The use of nanoscale fillers has led to the development of polymer nanocomposites and represents a radical alternative to these conventional polymer composites (ALEXANDRE; DUBOIS, 2000; GIANNELIS, 1996; SINHA; OKAMOTO, 2003). This new generation of composites exhibits significant improvements in modulus, dimensional stability, and solvent or gas resistance with respect to the pristine polymer. Nanocomposites also offer extra benefits such as low density, transparency, good flow, better surface properties, and recyclability. It is worth recalling that all these improvements are obtained at very low filler contents (generally lower than 5\%) (SORRENTINO; GORRASI; VITTORIA, 2007).

The extraordinary success of the nanocomposite concept in the area of synthetic polymers has stimulated new research on nanocomposites based on the use of the biodegradable polymers as a matrix.

Biodegradable plastics are polymeric materials in which at least one step in the degradation process is through metabolism in the presence of naturally occurring organisms (SORRENTINO; GORRASI; VITTORIA, 2007). Under appropriate conditions of moisture, temperature and oxygen availability, biodegradation leads to fragmentation or disintegration of the plastics with no toxic or environmentally harmful residue (CHANDRA; RUSTGI, 1998).

Biodegradable polymers can be classified according to their source (SORRENTINO; GORRASI; VITTORIA, 2007):

- Polymers directly extracted or removed from biomass (i.e. polysaccharides, proteins, polypeptides, polynucleotides);

- Polymers produced by classical chemical synthesis using renewable bio-based monomers or mixed sources of biomass and petroleum (i.e. polylactic acid or biopolyester); and

- Polymers produced by micro-organism or genetically modified bacteria (polyhydroxybutyrate, bacterial cellulose, xanthan, curdian, pullan).

Recently, several research groups have started the preparation and characterization of various kinds of biodegradable polymer nanocomposites showing properties suitable for a wide range of applications. So far, the most investigated biodegradable nanocomposites suitable for packaging applications are starch and derivates, polylactic acid, poly(butylene succinate), polyhydroxybutyrate, and aliphatic polyester (SORRENTINO; GORRASI; VITTORIA, 2007).

NPs can also be applied as reactive particles in packaging materials. These so-called nanosensors are designed to respond to environmental changes (e.g., temperature or moisture in storage rooms), degradation products of the food commodities, or contamination by micro-organisms. No data is available on possible migration of NPs into food using these applications. However, it is conceivable to assume that the use of active packaging releasing, into the food, NPs with antimicrobial functions (e.g., nano-silver and in more rare cases zinc-oxide NP), will lead to direct consumer exposure to (free) NPs. Hence, this urges the need for information on the effects of these NP to human health following chronic exposure. Moreover, attention should be paid to life-cycle analysis and effects on the environment (MORARU et al., 2003).

Bioactive packaging materials need to be able to keep bioactive compounds, such as prebiotics, probiotics, encapsulated vitamins or bioavailable flavonoids, in optimum condition until they are released in a controllable manner into the food product (LÓPEZRUBIO; GAVARA; LAGARON, 2006; GUERRA et al., 2005; BRODY, 2005). Bioactive-packaging materials can help to control oxidation of foodstuffs and to prevent the formation of off-flavors and undesirable textures of food. Bioactive compounds that are encapsulated into the packaging itself are a promising approach because this would allow the release of the active compounds in a controllable manner. Several already approved food additives could be used for such nanoencapsulation including carrageenan, chitosan, gelatin, polylactic acid, polyglycolic acid, and alginate (LÓPEZ-RUBIO; GAVARA; LAGARON, 2006; KUMAR, 2000; AGULLÓ et al., 2003).

In addition to food packaging, food preservation is also of great importance for the food industry. Food spoilages can be detected with the so-called nanosensors, for example, an array of thousands of nanoparticles designed to fluoresce in different colors in contact with food pathogens. Taking into account the crucial importance of time in food microbiology, the main aim of nanosensors is to reduce the time for pathogen detection from days to hours or even minutes (BHATTACHARYA et al., 2007). Such nanosensors could be placed directly into the packaging material, where they would serve as 'electronic tongue' or 'noses' by detecting chemicals released during food spoilage (LANGE et al., 2002; GARCIA et al., 2006). Other types of nanosensors are based on microfluidics devices (BAEUMMER, 2004) and can also be used to detect pathogens efficiently in real time and with high sensitivity. A major advantage of microfluidic sensors is their miniature format and their ability to detect compounds of interest rapidly in only microliters of required sample volumes, which has already led to widespread applications in medical, biological, and chemical analysis (VODINH; CULLUM; STOKES, 2001; MABECK; MALLIARAS, 2006). 


\subsection{Pathogen detection}

Outbreaks of disease have resulted in export bans and the collapsing of markets. Japan, for example, banned U.S. beef and beef products after a single case of Bovine Spongiform Encephalopathy (BSE) was detected in an eight-year-old cow imported into the United States from Canada. Japan is continuing to show resistance to fully reopening its borders. In the United Kingdom, the BSE crisis in the late 1990s led to a $40 \%$ decline in domestic beef sales and the complete loss of many export markets (ATKINSON, 2007). Scientists at the Kopelman Laboratory at the University of Michigan have been developing non-invasive bioanalytical nanosensors that could perhaps be placed in a cow's saliva gland to detect a single BSE prion particle long before the prion has had a chance to multiply and long before any symptoms of the disease are evident (DISCUSSION..., 2005).

Scientists at the University of Rochester Medical Center have demonstrated a new technology that rapidly and accurately detects E. coli bacteria. The technology uses a protein from the E. coli bacterium, a silicon chip, and a digital camera as part of its sensing system. The protein on the chip binds with any $E$. coli in the sample being tested. Once this binding has occurred, the surface of the chip is changed. The digital camera photographs this change for analysis and confirmation of detection (BIOLOGY..., 2005).

A portable device has been developed that would simultaneously detect numerous toxins, pathogens, and chemicals in foodstuffs. The process involves using nanowires and antibodies in such a way that a single test will be able to identify the presence, type, and concentration of contamination. Specific pathogen antibodies are attached to the individual nanowires, which are then placed on the food. If, for instance, the food product contains Salmonella, the Salmonella cells will bind with the Salmonella antibody on the nanowire. The nanowires are then exposed to fluorescent antibodies, which in turn are exposed to make the bacteria visible. Scientists have doubts about this process of "sandwich immunoassay" (DISCUSSION..., 2006).

\section{Nutraceuticals}

Nano-formulated food additives or supplements are available on the market, e.g., regulatory peptides from plants, nano-droplets/-clusters and nano-water. The applicants claim increased bioavailability but valid studies on relative bioavailability comparing these products with similar nonnano-formulated products are lacking (BOUWMEESTER et al., 2009).

\subsection{Nano-delivery systems}

An important class of NPs for application within food are nano-delivery systems (LETCHFORD; BURT, 2007; TAYLOR et al., 2005). Examples (Chart 2) range from novel pesticide formulations (e.g., increased crop adherence) to oral delivery systems for bioactive compounds. The latter is created for targeted delivery of bioactive compounds and to increase the bioavailability of these compounds. When used as a food additive or supplement, the delivery systems are commonly built from natural biopolymers of nanosize scale such as peptides, polysaccharides, or lipid monomers (CHEN; REMONDETTO; SUBIRADE, 2006; GRAVELAND-BIKKER; DE KRUIF, 2006; MOZAFARI et al., 2006). It is obvious that this application of NPs might result in unusually high consumer exposure to the enclosed compounds.

For delivery systems to be effective, the encapsulated active compounds must be delivered to the appropriate sites, their concentration maintained at suitable levels for long periods of time, and their premature degradation prevented (JELINSKI, 1999). NPs and nanospheres allow better encapsulation and release efficiency than traditional encapsulation systems and are particularly attractive since they are small enough to even be injected directly into the circulatory system (BODMEIER; CHEN; PAERATAKUL,1989; ROY et al., 1999).

Nano-encapsulation involves the incorporation, absorption, or dispersion of bioactive compounds in/at or on small vesicles with nano-diameters. The incorporated bioactive compounds may be protected against degradation, have improved stability and solubility (e.g., solubilizing a hydrophilic compound in hydrophobic matrices and vice-versa), and therefore might increase bioavailability and delivery to cells and tissues (LETCHFORD; BURT, 2007; TAYLOR et al., 2005). Reducing the size of the encapsulates into the nanoscale offers opportunities related with prolonged gastrointestinal retention time caused by bio-adhesive improvements in the mucus covering the intestinal epithelium (CHEN; REMONDETTO; SUBIRADE, 2006; MEDINA et al., 2007). Modulations of surface properties (e.g., coatings or bio-molecular flags) can enable targeted delivery of compounds. The latter field of application is, however, more developed in relation to biomedical applications (BOUWMEESTER et al., 2009).

Nano-encapsulates may consist of a core composed of one to several types of compounds surrounded by a wall or barrier (DINSMORE, 2002; LETCHFORD; BURT, 2007). These delivery systems have its roots in the pharmaceutical industry, where often synthetic polymeric nano-encapsulates are employed. For the application of nano-encapsulates into food, lipid- or natural- polymer-based capsules are most often studied or applied (CHEN; REMONDETTO; SUBIRADE, 2006).

\section{Lipid-based nano-delivery systems}

The main lipid-based nano-encapsulation systems that can potentially be used in food and food supplements are nanoliposomes, archaeosomes and nanocochleates (MOZAFARI et al., 2006).

Nanoliposomes are defined as bilayer lipid vesicles $(<30$ or $30-100 \mathrm{~nm}$ vesicles) possessing and maintaining nanometric size ranges during storage and application. Because of their unique properties, e.g., hydrophilic and hydrophobic regions, they can entrap, deliver, and release both water-soluble and lipidsoluble material (MOZAFARI et al., 2006). These may release their contents into cells upon e.g., encountering specific cellular enzymes, due to $\mathrm{pH}$ or thermo-sensitivity or after 'the binding of antigen whith the antibody-tagged (TAYLOR et al., 2005). 
Archaeosomes, which are liposomes made from Archaeobacteria, are even more thermostable and stress resistant if compared to normal liposomes. These are therefore considered ideal candidates to protect i.e., antioxidants during food processing (PATEL, 2000).

A very stable and precise delivery system is represented by "cochleates," stable phospholipid-divalent cation precipitates composed of naturally occurring materials, developed and patented by BioDelivery Sciences International Inc., Newark, N.J. (MORARU et al., 2003).

Nanocochleates have a multilayered structure consisting of a large, continuous, solid lipid bilayer sheet rolled up in a spiral fashion with little or no internal aqueous space (MOZAFARI et al., 2006); they deliver their contents to target cells through the fusion of the outer layer of the cochleate to the cell membrane. Nanocochleates have been used to deliver proteins, peptides and DNA for vaccine and gene therapy applications. Cochleates resist environmental attack, and their solid layered structure provides protection from degradation for the "encochleated" molecules, even when exposed to harsh environmental conditions or enzymes, including protection from degradation in the gastrointestinal tract, which makes them ideal candidates for oral delivery (ZARIF, 2003). They can be used for the encapsulation and delivery of many bioactive materials, including compounds with poor water solubility, protein and peptide drugs, and large hydrophilic molecules. It is possible to envision that such systems could be used in the nottoo-distant future for the encapsulation and targeted delivery/ release of functional food biomolecules (MORARU et al., 2003). At this moment, it has become possible to use liposomes to deliver functional components such as nutraceuticals, antimicrobials, and flavors to food (WERE et al., 2003).

The actual use of these delivery systems in food and food supplements is determined by their preparation procedure, which may involve non-food grade solvents and detergents that might leave residues in the delivery systems (MOZAFARI et al., 2006).

\section{Polymer-based nano-delivery systems}

Nano-encapsulates based on polymers are obtained by the polymerization of more than one type of monomer, typically one hydrophobic and one hydrophilic, so that the resulting molecule is composed of regions that have opposite affinities for an aqueous solvent. Natural polymers that are used are albumin (protein), gelatin (protein) (ZWIOREK et al., 2004), alginate (saccharide), collagen (protein), chitosan (saccharide), and the milk protein $\alpha$-lactalbumin (GRAVELAND-BIKKER; DE KRUIF, 2006). Protein-based nano-encapsulates are particularly interesting because they are relatively easy to prepare and can form complexes with polysaccharides, lipids, or other biopolymers. A wide variety of nutrients can be incorporated (CHEN; REMONDETTO; SUBIRADE, 2006). In addition, to date numerous copolymers have been synthesized leading to the formation of micelles, nanospheres, polymersomes, and nanocapsules (LETCHFORD; BURT, 2007).
Micelles are characterized by a core-shell architecture in which the inner core is composed of the hydrophobic regions of the amphiphilic molecules creating a cargo space for the lipophilic bioactive compound (CHEN; REMONDETTO; SUBIRADE, 2006). Nanospheres can be defined as solid colloidal particles in which bioactive compounds are dissolved, entrapped, encapsulated, chemically bound, or adsorbed to the polymer matrix. However, the central core can become more or less solid-like depending on the copolymer composition making it difficult to have a clear distinction between micelles and nanospheres (CHEN; REMONDETTO; SUBIRADE, 2006). Nanocapsules and polymersomes are colloidal-sized, vesicular systems in which the bioactive compound is confined within a cavity surrounded by a polymer membrane or coating. If the core is an oily liquid and the surrounding polymer a single layer the vesicle is referred to as a nanocapsule; these system have found utility in delivery of hydrophobic compound. If the core of the vesicle is an aqueous phase and the surrounding coating is a bi-layer polymer, the particle is referred to as a polymersome. These vesicles are analogous to liposomes and find utility in delivery of encapsulation of water-soluble compound, but they differ from liposomes in that the external bi-layer is composed of amphiphilic copolymers. Variation in composition, molecular geometry, and relative monomer lengths results in various physico-chemical properties and morphologies of the resulting nano-encapsulates (LETCHFORD; BURT, 2007).

Currently, greater fundamental understanding of polymerpolymer and polymer-nutraceutical interactions at the molecular level and their impact on functional properties of the delivery systems is required to ensure design of ideal nutraceutical carriers for use in the food industry.

\section{Nanotubes and membranes}

A newer generation of nanomaterials is represented by carbon nanotubes. Discovered in 1991 by the Japanese electron microscopist Sumio Iijima at NEC Corp., Tokyo, Japan, nanotubes are made by "winding" single sheets of graphite with honeycomb structures into very long and thin tubes that have stable, strong, and flexible structures. Nanotubes are the strongest fibers known - 10-100 times stronger than steel per unit weight - and researchers have been using them to make nanotube-reinforced composites with high fracture and thermal resistance to replace conventional ceramics, alumina, and even metals in building aircraft, gears, bearings, car parts, medical devices, sports equipment, and industrial food-processing equipment (MORARU et al., 2003).

Recent studies have suggested the use of carbon nanotubes for biological purposes, such as crystallization of proteins and building of bioreactors and biosensors. For biological applications, the insolubility of carbon nanotubes in aqueous media needs to be overcome. Dagani (2002) has solubilized single-wall carbon nanotubes in aqueous iodine-starch solutions, and Bandyopadhyaya et al. (2002) have obtained a similar result using aqueous solutions of gum arabic. Other solutions for solubilization of single-wall carbon nanotubes consist of functionalizing the tubes with glucosamine (POMPEO; RESASCO, 2002) or bovine serum albumin. 
The manufacturing of nanotube membranes has significant potential for use in food systems. Highly selective nanotube membranes can be used both for analytical purposes as part of sensors for molecular recognition of enzymes, antibodies, various proteins, and DNA and for membrane separation of biomolecules, such as proteins (LEE; MARTIN, 2002; ROUHI, 2002). The selectivity and yield of the membranes currently used in the food industry is not fully satisfactory, mainly because of the limited control of their structure and chemical affinity.

By functionalizing nanotubes in a desired manner, nanotube membranes can be tailored to efficiently separate molecules on the basis of both their molecular size and shape and their chemical affinity. For example, Lee and Martin (2002) have developed membranes that contain monodisperse gold nanotubes with inside diameters of $<1 \mathrm{~nm}$, which can be used either for separation of molecules or for the transport of ions between solutions placed on either side of the membrane. They were able to make the interior of the nanotubes hydrophobic, thus the nanotube membrane preferentially extracts and transports neutral hydrophobic molecules. While such technologies are still too expensive for industrial food applications, they could be applied in the future for the separation of food biomolecules with functional value (e.g., proteins, peptides, vitamins, or minerals), which would be used for food fortification or the manufacturing of dietary supplements or drugs (MORARU et al., 2003).

Another area of carbon nanotube-based applications is the development of electrically conductive membranes. The high length-to-diameter ratio of carbon nanotubes can be used to turn ordinary synthetic polymers, which are typically electrical insulators, into conducting polymers. In addition to their uses in the electronics and automobile industries, these polymers can also be utilized to develop novel membranes that will enhance separation and energy efficiency in the separation of flavor and nutraceutical molecules (MORARU et al., 2003).

The basic idea of this development is to incorporate minuscule carbon nanotubes uniformly into polymer substrates that can be then developed into membranes. These electrically conductive membranes can be resistance-heated to provide the thermal energy needed for some membrane separation processes that involve phase change. This could minimize the energy losses that occur when the feedstock is heated, enhance the heat transfer, and limit the detrimental effects of prolonged heating on the nutritional and sensory properties of the food/bioactive feedstock. Membrane pervaporation of food flavors, dehydration of alcohols by pervaporation or membrane distillation, and temperature-swing absorption of volatile liquids are just some examples of possible applications of such conducting membranes in the food and associated industries (MORARU et al., 2003).

High-performance nanoporous membranes can also be manufactured using high-surface-area nanoscale materials, such as clusters and nanocrystalline materials. Nanotechniques can be used to functionalize supported microfiltration or ultrafiltration polymeric membranes by filling their pores with polymeric or oligomeric liquids that have affinity for the compound of interest (JELINSKI, 1999). A nanoparticle-enhanced membrane that combines organic polymers with inorganic silica nanoparticles and enables large molecules to pass through more readily than small molecules was developed by Kingsley. The addition of the silica resulted in $>200 \%$ improvement in the flux and increased the permeability of the membrane, which challenges the common knowledge about membrane separation. The increased permeability was due to the NPs which, according to the author, pushed the polymer chains apart creating larger openings in the membrane's structure. The reported use of these membranes is to purify fuel (ethanol and methanol) inexpensively, but foodrelated applications could also become possible.

High-surface-area materials also have a great potential for the manufacturing of thin films for electronic and optical devices, nanoporous thermal barrier coatings, or adsorbents selective for amino acids and other biological molecules (COX, 1999). The latter is achieved using the molecular imprinting technique, which allows making artificial "locks" for "molecular keys" (RAMSTRÖM, 1996). Such ideas can be useful in food systems for building biosensors or creating efficient delivery systems (MORARU et al., 2003).

\section{Conclusions}

Nanotechnology has become increasingly important for the food sector. Promising results and applications have already being developed in the areas of food packaging and food safety. The incorporation of nanomaterials into food packaging will improve the barrier properties of packaging materials and should thereby help to reduce the use of valuable raw materials and the generation of waste, and the development of nanosensors to detect microorganisms and contaminants is a particularly promising application of food nanotechnology.

\section{References}

AGULLÓ, E. et al. Present and future role of chitin and chitosan in food. Macromolecular Bioscience, v. 3, n. 10, p. 521-530, 2003.

ALEXANDRE, M.; DUBOIS, P. Polymer-layered silicate nanocomposites: preparation, properties and uses of a new class of materials. Materials Science and Engineering, v. 28, p. 1-63, 2000 .

ATKINSON, N. The Impact of BSE on the UK Economy. [1999]. Disponível em: <http://www.iica.org.ar/Bse/14-\%20Atkinson. html>. Acesso em: 8 Mar. 2007.

AVELLA, M. et al. Biodegradable starch/clay nanocomposite films for food packaging applications. Food Chemistry, v. 93, n. 3, p. 467-474, 2005.

BAEUMMER, A. Nanosensors identify pathogens in food. Food Technology, v. 58, p. 51-55, 2004.

BANDYOPADHYAYA, R. et al. Stabilization of individual carbon nanotubes in aqueous solutions. Nano Letters, v. 2, p. 25-28, 2002.

BHATTACHARYA, S. et al. Biomems and nanotechnology based approaches for rapid detection of biological entitities. Journal of Rapid Methods and Automation in Microbiology, v. 15, p. 1-32, 2007.

BIOLOGY NEWS NET. Rochester scientists develop fast-working biosensor. 2006. Disponível em: <http://www.biologynews.net/ archives/2006/02/24/rochester_seientists_develop_fastworking biosensor.html>. Acesso em: 28. Aug. 2006. 
BODMEIER, R.; CHEN, H. G.; PAERATAKUL, O. A novel approach to the oral delivery of micro- or nanoparticles. Pharmaceutical Research, v. 6, p. 413-417, 1989.

BOUWMEESTER, H. et al. Review of health safety aspects of nanotechnologies in food production. Regulatory Toxicology and Pharmacology, v. 53, n. 1, p. 52-62, 2009.

BRODY, A. L. Edible packaging. Food Technology, v. 56, p. 65-66, 2005.

CHANDRA, R.; RUSTGI, R. Biodegradable polymers. Progress in Polymer Science, v. 23, p. 1273-1335, 1998.

CHAUDHRY, Q. et al. Applications and implications of nanotechnologies for the food sector. Food Additives \& Contaminants, v. 25, n. 3 , p. 241-258, 2008.

CHEN, H. D.; WEISS, J. C.; SHAHIDI, F. Nanotechnology in nutraceuticals and functional foods. Food Technology, v. 60, n. 3, p. 30, 2006.

CHEN, L. Y.; REMONDETTO, G. E.; SUBIRADE, M. Food proteinbased materials as nutraceutical delivery systems. Trends in Food Science \& Technology, v. 17, n. 5, p. 272-283, 2006.

DAGANI, R. Sugary ways to make nanotubes dissolve. Chemical \& Engineering News, v. 80, n. 28, p. 38-39, 2002.

DINSMORE, A. Colloidosomes: selectively permeable capsules composed of colloidal particles. Science, v. 298, n. 5595, p. 1006-1009, 2002.

DISCUSSION NEWS MEDIA. Instant, portable, simultaneous pathogen inspection. 2006. Disponível em: <http://www. foodproductiondaily-usa,com/news/ng.asp?n=69938-salmonellanano-wires-pathogens>. Acesso em: 28 Aug. 2006.

DISCUSSION NEWS MEDIA. Nanoscale technology: the future of food safety. 2005. Disponível em: <http://www.nutraingredientsusa.coni/news/ng.asp?n=60041-nanoscale-teehnoiogy-br $>$. Acesso em: 29 Aug. 2006.

DONALDSON, K.; SEATON, A. The Janus faces of nanoparticles. Journal of Nanoscience and Nanotechnology, v. 7, n. 12, p. 4607-4611, 2007.

GARCÍA, M. et al. Electronic nose for wine discrimination. Sensors and Actuators B: Chemical, n. 113, p. 911-916, 2006.

GIANNELIS, E. P. Polymer layered silicate nanocomposites. Advanced Materials, v. 8, p. 29-35, 1996.

GRAVELAND-BIKKER, J. F.; DE KRUIF, C. G. Unique milk protein based nanotubes: Food and nanotechnology meet. Trends in Food Science \& Technology, v. 17, n. 5, p. 196-203, 2006.

GUERRA, N. P. et al. Development of a bioactive packaging cellophane using Nisaplin as biopreservative agent. Letters in Applied Microbiology, v. 40, p. 106-110, 2005.

JELINSKI, L. Biologically related aspects of nanoparticles, nanostructured materials and nanodevices. In: SIEGEL, R.W.; HU, E.; ROCO, M. C. (Eds.). Nanostructure science and technology: a worldwide study. USA: NSTC; IWGN, 1999. Disponível em: <http:// www.wtec.org/loyola/nano/toc.htm>. Acesso em: 11 May 2002.

KUMAR, M. N. A review of chitin and chitosan applications. Reactive and Functional Polymers, v. 46, p. 1-27, 2000.

LABUZA, T. P.; BREENE, W. M. Applications of active packaging for improvement of shelf-life and nutritional quality of fresh and extended shelf-life foods. Journal of Food Processing and Preservation, v. 13, p. 1-69, 1988.

LAGARÓ, J. M. et al. Improving packaged food quality and safety. Part 2: Nanocomposites. Food Additives and Contaminants, v. 22, n. 10, p. 994-998, 2005.
LANGE, D. et al. Complementary metal oxide semiconductor cantilever arrays on a single chip: mass-sensitive detection of volatile organic compounds. Analytical Chemistry, v. 74, p. 3084-3095, 2002.

LEE, S. B.; MARTIN, C. R. Electromodulated molecular transport in gold-nanotube membranes. Journal of the American Chemical Society, v. 124, p. 11850-11851, 2002.

LETCHFORD, K.; BURT, H. A review of the formation and classification of amphiphilic block copolymer nanoparticulate structures: micelles, nanospheres, nanocapsules and polymersomes. European Journal of Pharmaceutics and Biopharmaceutics, v. 65, n. 3, p. 259-269, 2007.

LÓPEZ-RUBIO, A.; GAVARA, R.; LAGARON, J. M. Bioactive packaging: turning foods into healthier foods through biomaterials. Trends in Food Science \& Technology, v. 17, p. 567-575, 2006.

MABECK, J. T.; MALLIARAS, G. G. Chemical and biological sensors based on organic thin-film transistors. Analytical and Bioanalytical Chemistry, n. 384, p. 343-353, 2006.

MAYNARD, A. D. et al. Safe handling of nanotechnology. Nature, v. 444, n. 7117, p. 267-269, 2006.

MEDINA, C. et al. Nanoparticles: pharmacological and toxicological significance. British Journal of Pharmacology, v. 150, n. 5, p. 552-558, 2007.

MOORE, S. Nanocomposite achieves exceptional barrier in films. Modern Plastics, v. 76, n. 2, p. 31-32, 1999.

MORARU, C. I. et al. Nanotechnology: a new frontier in food science. Food Technology, v. 57, n. 12, p. 24-29, 2003.

MOZAFARI, M. R. et al. Recent trends in thelipid-based nanoencapsulation of antioxidants and their role in foods. Journal of the Science of Food and Agriculture, v. 86, n. 13, p. 2038-2045, 2006.

NEL, A. et al. Toxic potential of materials at the nanolevel, Science, v. 311, n. 5761, p. 622-627, 2006.

OBERDORSTER, G.; STONE, V.; DONALDSON, K. Toxicology of nanoparticles: a historical perspective. Nanotoxicology, v. 1, n. 1, p. 2-25, 2007.

PATEL, G. In vitro assessment of archaeosome stability for developing oral delivery systems. International Journal of Pharmaceutics, v. 194, n. 1, p. 39-49, 2000.

POMPEO, F.; RESASCO, D. E. Water solubilization of single-walled carbon nanotubes by functionalization with glucosamine. Nano Letters, v. 2, p. 369-373, 2002.

QUARMLEY, J.; ROSSI, A. Nanoclays. Opportunities in polymer compounds. Industrial Minerals, n. 400,. 47-49, 52-53, 2001.

RAMSTRÖM, O. Molecular imprinting technology. A way to make artificial locks for molecular keys. Sweden: Center for Chemistry and Chemical Engineering, Lund University, 1996. Disponível em: <http://www.smi.tu-berlin.de>. Acesso em: 24 June 2003.

ROUHI, M. Novel chiral separation tool. Chemical \& Engineering News, v. 80, n. 25, p. 13, 2002.

ROY, K. et al. Oral gene delivery with chitosanBDNA nanoparticles generates immunologic protection in a murine model of peanut allergy. Nature Medicine, v. 5, p. 387-391, 1999.

SCIENTIFIC COMMITTEE ON EMERGING AND NEWLY IDENTIFIED HEALTH RISK - SCENIHR. Opinion on: the scientific aspects of the existing and proposed definitions relating to products of nanoscience and nanotechnologies. Brussels: European Commission Health; Consumer Protection Directorate-General, 2007.

SINHA, S.; OKAMOTO, M. Polymer/layered silicate nanocomposites: a review from preparation to processing. Progress in Polymer Science, v. 28, p. 1539-1641, 2003. 
SORRENTINO, A.; GORRASI, G; VITTORIA, V. Potencial perspectives of bio-nanocomposites for food packaging applications. Trends in Food Science and Technology, v. 18, p. 84-95, 2007.

STUCKY, G. D. High surface area materials. In: WORKSHOP ON R\&D STATUS AND TRENDS IN NANOPARTICLES, NANOSTRUCTURED MATERIALS, AND NANODEVICES IN THE UNITED STATES - WTEC, 1997. Proceedings... Disponível em: <http://www.wtec.org/loyola/nano/US.Review/07_03.htm>. Acesso em: 12 Sep. 2003.

TAYLOR, T. M. et al. Liposomal nanocapsules in food science and agriculture. Critical Reviews in Food Science and Nutrition, v. 45, n. 7-8, p. 587-605, 2005.

VERMEIREN, L. et al. Developments in the active packaging of foods. Trends in Food Science and Technology, v. 10, p. 77-86, 1999.

VO-DINH, T.; CULLUM, B. M.; STOKES, D. L. Nanosensors and biochips: frontiers in biomolecular diagnostics. Sensors and Actuators B, v. 74, p. 2-11, 2001.
WEISS, J.; TAKHISTOV, P.; McCLEMENTS, J. Functional materials in food nanotechnology. Journal of Food Science, v. 71, n. 9, p. R107-R116, 2006.

WERE, L. M. et al. Size, stability, and entrapment efficiency of phospholipid nanocapsules containing polypeptide antimicrobials. Journal of Agricultural and Food Chemistry, v. 51, n. 27, p. 8073-8079, 2003.

WOODROW WILSON INTERNATIONAL CENTER FOR SCHOLARS. Assuring the safety of nanomaterials in food packaging: the regulatory process and key issues. 2008. Disponível em: <http://www.nanotechproject.org/process/assets/files/6704/ taylor_gma_pen_packaging1.pdf $>$. Acesso em: 28 Aug. 2008.

ZARIF, L. Nanocochleate cylinders for oral \& parenteral delivery of drugs, Journal of Liposome Research, v. 13, n. 1, p. 109-110, 2003.

ZWIOREK, K. et al. Gelatine nanoparticles as a new and simple gene delivery system. Journal of Pharmacy \& Pharmaceutical Sciences, v. 7, n. 4, p. 22-28, 2004. 